\title{
Competition in the Nigerian Telecommunications Industry
}

\author{
Olumide K. Obayemi \\ Lagos State University, Lagos, Nigeria \\ Email: obayemilaw@hotmail.com
}

Received 9 October 2014; revised 26 November 2014; accepted 10 December 2014

Copyright (c) 2014 by author and Scientific Research Publishing Inc.

This work is licensed under the Creative Commons Attribution International License (CC BY). http://creativecommons.org/licenses/by/4.0/

(c) (i) Open Access

\section{Abstract}

A certain means of improving the Nigerian socio-economic environment is through the introduction of healthy laissez faire, free market economy, and competitive economic environment that is strongly rooted equal and easy access to raw materials, workforce, imported raw materials and machineries for production and distribution that would be available to all businesses and manufacturers. There must be rules that eschew nepotism, monopoly, and/or oligopoly. History has always shown that research, development, and innovation thrive in an economic environment founded on freedom, equality and unhindered capacity. This work, therefore, examines and appraises the rules and regulations that have been instituted to encourage healthy competition and forestall antitrust practices among Nigerian businesses. Further, it proffers suggestions for improvement of the Nigerian antitrust rules, in view of multiplicity of legislation covering similar/ identical subject matters. This work reviews the efficacy of the rules promoting competition, within the context of the Nigerian telecommunication sector, and argues for harmonization of all legislation prohibiting anti-trust acts, in order to set definite and coherent standards for all stakeholders. The work further examines the need for necessary reforms that would discourage anti-trust practices and help to achieve the Nigerian government's goal of attracting foreign investment. In addition, the author looks at the expeditious passage of the Federal Competition Commission Bill 2005 (FCCB) and the setting up of the Federal Competition Commission (FCC), whose aim is to regulate, prevent and punish anti-competitive practices, regulate Mergers, Takeovers and Acquisitions, and protect regulated industries, in every sector and location in Nigeria. In the end, the accompanying suggestions for reform will invariably impact Nigeria's economic, social, and political competitiveness at the global stage.

\section{Keywords}

Telecommunication, Antitrust, Competition, Merger 


\section{Introduction}

No doubt, Nigeria needs strong and effective legislation that would make its economy and business environments more competitive, compared to similar economies at the global arena. From the data released by the World Economic Forum Global Competitiveness Index (GCI) rankings (Global Competitiveness Report 20132014), Nigeria occupies the $120^{\text {th }}$ position out of 144 countries of the world. In detail, Nigeria only has positive rankings of $42^{\text {nd }}$ on macroeconomic environment and $32^{\text {nd }}$ on market size, respectively. Nigeria's uncompetitive environment is glaring from its $129^{\text {th }}$ ranking in institutions, $135^{\text {th }}$ in infrastructure, $146^{\text {th }}$ in health and primary education, $120^{\text {th }}$ in higher education, $108^{\text {th }}$ in technological readiness, and $100^{\text {th }}$ in innovation, respectively (The Global Competitiveness Index 2013-2014: Table 3: The Global Competitiveness Index 2013-2014 rankings and 2012-2013 comparisons).

A certain means of improving the Nigerian socio-economic environment is through the introduction of healthy laissez faire, free market economy, and competitive economic environment that is strongly rooted equal and easy access to raw materials, workforce, imported raw materials and machineries for production and distribution that would be available to all businesses and manufacturers. There must be rules that eschew nepotism, monopoly, and/or oligopoly. History has always shown that research, development, and innovation thrive in an economic environment founded on freedom, equality and unhindered capacity.

This work, therefore, examines and appraises the rules and regulations that have been instituted to encourage healthy competition and forestall antitrust practices among Nigerian businesses. Further, it proffers suggestions for improvement of the Nigerian antitrust rules, in view of multiplicity of legislation covering similar/identical subject matters.

Thus, the present debate about whether the recent GCI rankings are fair to Nigeria, i.e., as to whether Nigeria's $120^{\text {th }}$ position out of the 144 countries rated actually reflects the country's true reality is too critical to ignore, and there are real dangers that rather than reflect deeply and inwardly on the lessons of the GCI, on its ranking pillars such as institutions, infrastructure, macroeconomic environment, health, and education among others, Nigeria may end up living in denial of its true reality (Akanmu, 2014).

Since the return to democratic government, on $29^{\text {th }}$ May, 1999, Nigeria has embarked on the introduction of open market legislation, removal of limitations on foreign ownership, granting of financial incentives to Nigerian investors, importation tariff elimination, pioneer status and tax incentives, the elimination of restrictions placed on foreign capital importation, the reduction of import duties, and an overhauling of investment legislation (Obayemi, 2014). For instance, Section 9(1) of the National Broadcasting Commission ("NBC") was established by Decree No. 38 of 1992 that has subsequently been amended by the National Broadcasting Commission (Amendment) Decree No. 55 of 1999, now states as follows:

The Commission shall, in the consideration of an application or a licence under this Decree, be satisfied that the applicant inter alia

a) is a body corporate registered under the Companies and Allied Matters Decree 1990 or a station owned, established or operated by the Federal, State or Local Government;

b) can demonstrate to the satisfaction of the Commission that he is not applying on behalf of any foreign interest; $\ldots$

In addition, under the Nigeria Export Processing Zones Act, Cap N107 LFN 2004 (NEPZA Act) and Oil and Gas Export Processing Zones Act No. 63, of 1992, (OGEPZA), for companies that locate their businesses in the Free Trade Zones (FTZ) levies, duties and foreign exchange regulations do not apply to them, and it also follows that activities that are undertaken in the zone are, therefore, tax-exempt, along with the incentive that imports of materials for use in the zone are also duty-free.

There are now the Pioneer Status Incentive Regulations 2014, enacted by the Nigerian Investment Promotion Commission (NIPC). The Regulations have an effective date of 30 January 2014, and provide additional conditions to those contained in the Industrial Development (Income Tax Relief) Act for processing an application for Pioneer Status Incentive. Further, they provide an update on the list of requirements to be provided by applicants, in addition to the application forms. There is also a service charge of $2 \%$, based on estimated tax savings to be paid to the NIPC. "Mineral Oil Prospecting and Production" was recently added to the list of industries that could benefit from the grant of tax holidays as pioneer companies that could benefit from tax holidays, as obtainable under the Companies Income Tax Act, Cap C21, Laws of the Federation of Nigeria (2004) (CITA). 
Certainly, Nigeria has evolved from the colonial and post-independence period, during which the Nigerian government maintained a monopoly of the fixed telephone-based telecommunication industry. The old era was one of exclusion of private investors, absence of competition, non-accountability, and unquestionable governmental regulation. The present buoyant Nigerian telecommunication market is attributable to two (2) unrelated events. First was the passing of the 1997 World Trade Organization (WTO)'s General Agreement on Trade and Services (GATS)'s Agreement on Basic Telecommunications (WTO Background Documents 1997), which demanded structural reformations and amendment in member-states' telecommunication laws. Second was the return to democratic government in Nigeria, in May 1999, after which the federal government embarked on privatization, commercialization, and divestiture of public companies to private ownership (Awosika, 2014).

One of the beneficiaries of the improvised regulatory economic environment was the telecommunication sector. Prior to 1999, the sector was regulated by the Nigeria Communication Act No. 75 of 1992 (NCA 2004). Since 1999, the Nigerian Communication Commission (NCC), set up under the NCA 1992, has liberalized the telecom sector, a step that has since led to the fastest growing mobile market in the world, while attracting over \$3billion investment between 2000 and to date. Thus, within the preceding decade, the introduction of the Global System for Mobile Communications (GSM) in Nigeria has significantly impacted the nation's economy in a variety of ways, besides enhancing personal and corporate communications, and generally improving quality of life across the country. It necessarily follows that with liberalization and deregulation also came influx of capital and wealth. This necessitated the demand for institutionalized structures and control to curb unbridled sharp anti-trust business practices. With the spike in telecom business investments, it is necessary that the economic policies, investment goals, aim, and intent of the government should not be defeated.

As stated earlier, this work reviews the efficacy of the rules promoting competition, within the context of the Nigerian telecommunication sector, and argues for harmonization of all legislation prohibiting anti-trust acts, in order to set definite and coherent standards for all stakeholders. The work further examines the need for necessary reforms that would discourage anti-trust practices and help to achieve the Nigerian government's goal of attracting foreign investment. In addition, the author looks at the expeditious passage of the Federal Competition Commission Bill 2005 (FCCB) and the setting up of the Federal Competition Commission (FCC), whose aim is to regulate, prevent and punish anti-competitive practices, regulate Mergers, Takeovers and Acquisitions, and protect regulated industries, in every sector and location in Nigeria. In the end, the accompanying suggestions for reform will invariably impact Nigeria's economic, social, and political competitiveness at the global stage.

\section{Constitutional and Legislative Issues under Nigerian Competition (Anti-Trust) Laws}

The starting point for evaluating competition (anti-trust) laws in the Nigerian telecom market sector entails examining the Constitution of the Federal Republic of Nigeria (1999), which provides, at Section 16, as follows:

16. 1) The State shall, within the context of the ideals and objectives for which provisions are made in this Constitution...

$* * *$

d) without prejudice to the right of any person to participate in areas of the economy within the major sector of the economy, protect the right of every citizen to engage in any economic activities outside the major sectors of the economy.

2) The State shall direct its policy towards ensuring:

a) the promotion of a planned and balanced economic development;

b) that the material resources of the nation are harnessed and distributed as best as possible to serve the common good;

c) that the economic system is not operated in such a manner as to permit the concentration of wealth or the means of production and exchange in the hands of few individuals or of a group;...

From the above, it is clear that the Constitution aspires to ensure that the nation's wealth and economic system are not operated in such a manner as to permit the concentration of wealth or the means of production and exchange in the hands of few individuals or a group; therefore, consistent with the liberalization of the Nigerian telecommunications industry with post-May 1999, the NCC commenced the facilitation of market entries by diverse marketers through the introduction of transparent processes in licensing various communications services. 
While the whole of Chapter II of the Nigerian Constitution is not justiciable, however, the current global trend is that such provisions should continue to guide and drive the policy objectives of every government.

The result was that Nigeria became the fastest growing telecommunications market in Africa, after rising from 500,000 telephone subscribers in 2001 to over 108 million as of December 2012 (Web Trends Nigeria 2009). These giant strides in the telecommunications industry, over the last decade, were the direct consequences of enabling regulatory environment created by the Government through the NCC, and the readiness of financial institutions to finance businesses entering the Telecom sector (We are Social, Global Digital Statistics 2014).

For instance, in 2009, First City Monument Bank Plc (FCMB) was named as the "Best Telecom Supporting Bank in Nigeria" at the Nigerian Annual Telecoms Awards (First City Monument Bank Plc (FCMB) 2009), after showing strong commitment and support to the telecoms sector. FCMB's contribution was stated thus:

"The overwhelming initial financing support your bank offered the early beginners of telecom services remains unforgettable in the making of those strong brands. Such strong brands include the then Econet, now Zain, and Helios Towers in the Infrastructural sub-Sector. FCMB's supports were indeed commendable and deserving of an award as this."

Consequently, taking public and private support for the telecom industry together, the tremendous growth of the telecom industry has similarly and effectively led to the increased maturity and sophistication of individual networks, which have further ushered in intense competition amongst the industry players. As a result, while the NCC has recognized that effective competition in the various communications markets in Nigeria will, in turn, encourage sustainable investment, growth, and innovation to the benefit of the entire Industry and its consumers, the NCC has come to acknowledge that market conditions may preclude effective competition in certain market segments. As a result, the NCC has published the Nigerian Competition Practices Regulations (2007).

Yet, uncertainty, which pervades most areas of Nigerian statutory regulation, has slipped into the Nigerian telecom sector. Thus, it appears that the regulation of competition is shared between the NCC, Securities and Exchange Commission (SEC) under the Investment and Securities Act, Cap 29, Laws of the Federation of Nigeria ("ISA 2007"), and, where the field of telecom intersects with energy, the Nigerian Electric Regulatory Commission, 2005 (NERC 2005). In addition, the Federal Inland Revenue Service (FIRS), under Section 29(12) of the Nigeria Companies Income Tax Act (CITA 2004), also has power to issue clearance certificates regarding outstanding capital gains tax that may occur.

Section 118, of the ISA 2007, identifies three broad categories of merger threshold that constitute merger control: a) small merger (transactions involving N500,000,000.00); b) intermediate merger (transactions between N500,000,000.00 - N5 billion); and c) Upper merger (transactions involving N5 billion and above). While the small merger does not require a prior approval from SEC, notice, upon conclusion of the merger to the SEC is required.

While section 90 of the Nigerian Communications Act 2004 (NCA 2004) appears to confer, exclusively, on the NCC the power to regulate competition in the telecom sector, however, Section 118 of the Investment and Securities Act ("ISA 2007"), also vests in SEC the power of merger control, i.e., either to approve or to disapprove any application for intermediate and/or large mergers in Nigeria, with the Federal High court having the power to sanction such mergers.

Compounding the legislative imbroglio above is the fact that there is also the Electric Power Sector Reform Act of 2005, which also has its own antitrust regulation provisions.

\section{Evaluation of Policies and Theories of Competition/Anti-Trust Laws in Nigeria}

Competition laws, a.k.a. anti-trust laws, are meant to provide level playing field and adequate legal protection for competition among businesses (American Bar Association, 2008). Such rules form the foundation of the Nigerian free market economy. While not fully developed, Nigerian anti-trust laws seek to promote the interests of consumers, support unfettered markets, and must result in lower prices and more choices. Competition laws also seek to enhance access to products, reduce costs, improve quality, and increase varieties/choices (Obayemi \& Adegbola, 2014).

Without regulations, businesses may enter into anti-competitive agreements, or take actions that constitute abuse of market power, or create monopolistic market conduct and market structure (Shaffer, 2004). An abuse of 
market power takes place where one of the market suppliers possesses enough market power to undercut the other suppliers and so make it difficult for the latter to operate in the market (Shaffer, 1992). Further, the powerful supplier may outrightly force others to go out of business and, following this, it may take control of the entire market and so exact exorbitant prizes on the consumers (Aihevba, 2006). Along the same line, anti-competitive agreements take place when all, or most, suppliers in a geographical area or within a specific market sector come together and enter into agreements by which they can sell their products at artificial practices (DePemphilis, 2013).

Further, the creation of highly concentrated markets in the hands of few induces anti-competition behaviour, because the possibility of new businesses entering the market would be nil (PanAfrican Capital Plc, 2011), with attendant consequence of manufacturing alternative products stifled out of existence (Ugwunta, Ani, Ugwuanyi, \& Ugwu, 2012). Thus, where there is only one supplier, there is a monopoly. Where there are few suppliers, we have oligopoly (Dimgba, 2009).

However, this is not to conclude that there are no advantages, where there are cooperation and agreements between businesses to merge and combine towards forming stronger conglomerates. There are several advantages of mergers and acquisitions (Fagbure, 2014).

First, it allows an easy passage/entry of a foreign business to enter into the Nigerian economy. Burger King from the United States might have a hard time commencing business afresh in Nigeria, with regard to logistics, staffing, sourcing raw materials, and expertise. Acquiring the shares of, or merging with, a pre-existing fast food enterprise would serve as an easy vehicle to make a quick and less expensive in-road/emergence in Nigeria (Obayemi \& Adegbola, 2014).

Second, where a company is going out of business, a merger with a pre-existing business is a better choice over and above filing for bankruptcy and injuring loyal staff, creditors, and suppliers of raw materials. To file for bankruptcy and render several people jobless is less advantageous than selling the business to new owners, who will absorb the business' liabilities, as part of their growing empire (Obayemi \& Adegbola, 2014).

Third, where economic downturn persists, and in order to raise enough capital to stay afloat, corporations in the same line of business may combine to raise sufficient income to survive. For example, where the cost of importing newsprint materials has become exorbitant, major newspaper companies may merge, so as to pool resources together to succeed (Obayemi \& Adegbola, 2014).

Fourth, expansion into a new geographical area may be achieved by the acquisition of a pre-existing corporation. Where Nigerian Breweries intends to expand its market into Osun State, it is preferable if it acquires International Breweries- the producers of Trophy Larger beer.

Fifth, where the Target corporation's Research and Development department has renowned experts and the acquiring corporation possesses advantages in other areas, such as networking, manual labour, and fleets of truck, the two corporations may combine to utilize their individual amenities (Obayemi \& Adegbola, 2014).

Sixth, where foreign and local businesses are involved, it is better if a reputable local company were acquired to stimulate the immediate logistics and business concerns after commencement of business locally (Obayemi \& Adegbola, 2014).

Seventh, business combinations give the business owner the residual right to alienate his interests in the business (Obayemi \& Adegbola, 2014).

In effect, it is not all bad news where mergers, acquisitions, restructurings, and business combinations are concerned.

\section{A Review of the Draft Nigerian Federal Competition Commission Bill 2005 (FCCB)}

Since the May 1999 return to civilian rule, there have been four (4) attempts at drafting a Nigerian Competition Bill. The first effort was on June 18, 2001, when the Competition and Anti-trust Reform Steering Committee was inaugurated by the House of Representatives to formulate a Competition Policy for Nigeria, along with the Bureau of Public Enterprises (BPE). The result was the Federal Competition Commission Bill (FCCB).

Also, in 2002, another version of the Executive Bill was submitted by the erstwhile Federal Ministry of Commerce and Industry (now known as the Federal Ministry of Industry, Trade, and Investment).

Further, in 2004, Honourable Halims Agoda sponsored/presented another version, the National Anti-trust (Prohibition, Enforcement etc.) Bill to the House of Representatives. 
Finally, in 2005, Hon. Chidi Duru also sponsored another version of the Competition (Anti-trust) Bill to the House of Representatives.

All the bills have been harmonized into the FCCB that is still awaiting passage and assent. The draft FCCB contains 115 sections, 16 parts, along with 3 schedules. For the first time, it attempts to set up an independent governmental agency similar to the Federal Trade Commission's Bureau of Competition, as obtains in the United States, which is to enforce Nigerian anti-trust laws. This is the Federal Competition Commission (FCC) which is to regulate, prevent and punish anti-competitive practices, regulate Mergers, Takeovers and Acquisitions, and protect regulated industries in every sector and location in Nigeria.

As stated, the FCCB sets up the FCC with the following objectives:

a) promote the efficiency, adaptability, and development of the Nigerian economy;

b) provide consumers with competitive prices and product choices;

c) promote employment and advance the social and economic welfare of Nigerians;

d) ensure that small and medium enterprises have an equitable opportunity to participate in the Nigerian economy, and

e) protect Nigerian industries from unfair trade practices.

Section 2 of the FCCB states that the objects of the FCCB are to promote a) the balanced development of the Nigeria economy; b) the welfare and interests of consumers, and provide them with price and product choices; c) maintain and encourage competition and enhance economic efficiency in production, trade, and commerce; d) expansion of opportunities for domestic enterprises to participate in world markets; e) enhance the ability of small and medium enterprises to compete effectively; and f) prohibit restrictive business practices which prevents, restricts or distorts competition, or constitutes the abuse of a dominant position of market power in Nigeria.

Section 9 of FCCB states the functions of the FCCB to include formulating measures to increase market transparency, including weight and measures administration, initiating policy review of commercial activities in Nigeria to ascertain anti-competitive and restrictive practices that may adversely affect the economic interest of consumers, carrying out investigations or inquires, in relation to the conduct of business, that will enable it to determine whether any person is engaging in business practices, in contravention of the Act, and initiating actions for such violations, amongst others.

Toward controlling anti-competition practices, the FCCB, under Sections 36 and 39 sets a $40 \%$ threshold, as a basis for determining when a person or corporation would be taken to occupy a dominant position in the market to amount to antitrust activities.

First, section 36 of the FCCB defines what amounts to a dominant position thus:

36. For the purposes of this Act, one or more enterprises hold a dominant position in the relevant market if, singularly (by itself) (including activities involving an interconnected or affiliated company), or collectively, it or they has or have a share of more than forty percent of the relevant market, or if it or they, otherwise, has or have the ability to control prices or to exclude competition or to behave to an appreciable extent independently of its competitors, customers, or suppliers.

Section 37 of FCCB also defines what constitutes an abuse of dominant position thus:

37. 1) Subject to the provisions of sub-section 3) of this section, any conduct on the part of one or more enterprises which amounts to the abuse of a dominant position in a market is prohibited.

2) An enterprise abuses a dominant position, if it impedes the maintenance or development of effective competition in a market and, in particular, if it

a) restricts the entry of any other enterprise into that or any other market;

b) prevents or deters any enterprise from engaging in competitive conduct in that or any other market;

c) eliminates or removes any enterprise from that or any other market;

d) directly or indirectly imposes unfair purchase or selling prices or other anti-competitive practices;

e) limits production of products to the prejudice of consumers;

f) makes the conclusion of agreements subject to acceptance by other parties of supplementary obligations which, by their nature, or according to commercial usage, have no connection with the subject of such agreements, and

g) engages in any business conduct that results in the exploitation of its customers and suppliers, includ- 
ing, but not limited to, such conducts as exclusive dealing, market restriction, or tied selling.

***

4) An enterprise may be treated as abusing its dominant position in enforcing, or seeking to enforce, the rights referred to in subsection 2) b) of this section, if the Commission is satisfied that the exercise of those rights

a) has the effect of unreasonably lessening competition in a market, and

b) impedes the transfer and dissemination of technology...

As a result, Section 38 states the actions that can be taken by the FCC, in relation to abuse of dominant position, including investigation, cease and desist order, and prohibition.

38. 1) Where the Commission has reason to believe that an enterprise, or enterprises, holding a dominant position in a relevant market, in accordance with section 36, has abused, or is abusing, that position, the Commission may, subject to section 40 of this Act, conduct an investigation into the matter.

2) If the Commission finds that an enterprise or enterprises has or have abused, or is abusing, dominant position and that the abuse has had, is having, or is likely to have, the effect of lessening competition substantially in a market, the Commission shall prepare a report indicating the practices that constitute the abuse and shall

a) notify the enterprise, or enterprises, of its findings, accompanied by a copy of the report, and

b) direct the enterprise, or enterprises, to cease the abusing practice forthwith, or not later than six months, after receipt of the notice.

3) Where the Commission finds that the abusive practice constitutes tied selling, the Commission shall prohibit the enterprise, or enterprises, concerned from continuing that practice forthwith.

4) If the Commission finds that the abusive practice is exclusive dealing, or market restriction, it may prohibit the major supplier of products in a market, which is likely to

a) impede entry into, or expansion of, an enterprise in the market, and

b) impede introduction of productions into, or expansion of, sales of products in the market with the effect of lessening competition.

5) The Commission may prohibit the supplier, referred to in subsection 4), from continuing to engage in market restriction or exclusive dealing, or order that supplier to take such other action as, in the Commission's opinion, is necessary to restore or stimulate competition, in relation to the products.

6) This section shall not apply, in relation to exclusive dealing or market restriction, between or among affiliated or interconnected companies.

Section 39 of FCCB restates the $40 \%$ threshold for determining abuse of dominant position.

39. 1) The Commission shall not investigate an enterprise, under this section, unless it is satisfied that it controls more than forty percent of the market. When an enterprise is in dominant position.

2) For the purpose of subsection 1) of this section, an enterprise controls more than forty percent of a market if, in cases where the market relates to the supply, or, as the case may be, the export from Nigeria, of products of any description, more than forty percent of all the products of that description, which are supplied or produced in Nigeria, are supplied by, or to that, enterprise, or are produced by that enterprise or a group of affiliated or interconnected companies, of which the enterprise is a part.

3) Where the market relates to the export of products, a dominant position shall be taken to exist, both in relation to exports of products of that description from Nigeria generally, and from Nigeria to each country taken separately has, as its object, the regulation of competitive activities.

The provisions of the FCCB are salutary, exhaustive, and definitive. When it eventually passes from the legislature, it is hoped that the FCC will gradually step into its statutory role and effectively regulate competition in Nigeria. However, other statutes do not replicate the $40 \%$ threshold for making findings of antitrust activities.

\section{Regulation of Competition under the Nigerian Communications Act 2004, (NCA 2004)}

While the draft FCCB bill seeks to cover all anti-trust/competition issues across all sectors in Nigeria, the NCA 2004 proposes to regulate anti-trust issues solely within the telecommunication sector and, therefore, directs its 
focus at licensees of NCC. A review of the NCA shows that the NCC's functions and duties are set out in Section 4 of NCA to include:

a) the facilitation of investments in, and entry into, the Nigerian market for the provision and supply of communications services, equipment, and facilities;

b) the protection and promotion of the interests of consumers against unfair practices, including, but not limited to, matters relating to tariffs and charges and the availability and quality of communications services, equipment, and facilities, and

c) the promotion of fair competition in the communications industry and protection of communications services and facilities providers from the misuse of market power or anti-competitive and unfair practices by other service or facilities providers (section 4(d)) (NCA 2004: Section 4).

Of importance is the fact that Section 90 of NCA states that the NCC shall have exclusive competence to determine, pronounce upon, administer, monitor, and enforce compliance of all persons with competition laws and regulations, whether of a general or specific nature, as it relates to the Nigerian communications market. For instance, the NCA empowers the NCC to determine whether a licensee is in a dominant position in any aspect of the Nigerian communications market (NCA 2004: Section 90(1)). It also provides that the NCC may publish guidelines and regulations that clarify how it shall apply the test of “dominant position” to licensees. These guidelines may specify the matters, which the NCC may take into account in determining dominance (NCA 2004: Section 90(2) \& (3)). The NCA also authorises the NCC to direct a licensee in a dominant position in the communications market to cease a conduct in that market which has, or may have, the effect of substantially lessening competition in any communications market and to implement appropriate remedies (NCA 2004: Section 92(4)).

Enhancing the NCC's regulatory role and powers, in 2007, the NCC, as empowered by the NCA, published its Regulations on Competition Practices (Nigerian Competition Practices Regulations 2007) which:

a) provide further guidance on the standards and procedures, which the NCC will apply in determining whether a particular conduct constitutes substantial lessening of competition for the purposes of the NCA;

b) clarify what agreements or practices the NCC will find to be anti-competitive and, thus, prohibited under the NCA;

c) provide further guidance on the standards and processes, which the Commission will apply in determining whether a Licensee has a dominant position in one or more communications markets; and

d) clarify what conduct the Commission will find to be an abuse of dominance, and subject to a "cease conduct" direction, under the NCA.

We submit that the exclusive jurisdiction conferred on the NCC will definitely invoke litigations among stakeholders, because such exclusivity will definitely appear to trump the SEC and/or FCC's jurisdiction, where the telecom business involved is also a publicly-traded company, subject to the SEC/NSE's jurisdiction. It is against this background that we suggest harmonization of the NCA with other legislation regulating competition issues.

\section{Rules under the Nigerian Competition Practices Regulations (2007)}

Pursuant to sections 70 and 90 of the NCA and all other powers enabling it, the NCC, on December 7, 2007, promulgated the Nigerian Competition Practices Regulations (2007).

Unlike the 40\% threshold stated under Sections 36 and 39 of the FCCB, Regulation 27 of NCC Regs contains a lower threshold of $10 \%$ as well as the procedure to be adopted by the NCC, in deciding whether or not to approve business combinations and activities in the telecom sector that will not constitute antitrust violations.

Unlike Sections 35 and 39 of the Federal Competition Commission Bill (FCCB) which jointly state a threshold of $40 \%$ control of the market for invoking antitrust evaluation, Regulation 27 of NCC Regulations states only a threshold of $10 \%$ acquisition of the licensed target company is necessary to require the approval of the NCC.

27. The Commission shall apply the review procedures, described in this Part of the Regulations, to the following transactions:

a) transactions that involve the acquisition of more than $10 \%$ of the shares of a Licensee;

b) any other transaction that results in a change, in control of the Licensee;

c) any transaction that results in the direct or indirect transfer or acquisition of any individual licence, pre- 
viously granted by the Commission pursuant to the Act; and

d) where the Commission determines, based on the preliminary information provided by a Licensee in its initial transaction notification, that the transaction may, result in a substantial lessening of competition in one or more communications markets, or may result in the Licensee or any successor company having a dominant position in one or more communications markets.

To further, restate the exclusive jurisdiction of the NCC, Regulation 28 of NCC Regs mandatorily states that prior approval of the NCC would be required for transactions made under Regulation 27 of NCC Regs:

28. 1) Where a proposed transaction involves any of the circumstances described in Regulation 27 a), b) or c), the transaction will require prior notification and the approval of the Commission.

2) The Licensee shall submit a written notification and request for approval, at least, sixty (60) days, prior to the completion date for the intended transaction, to be accompanied by, at least, the following information:

a) the identification of all persons involved in the transaction, including buyers, sellers, their shareholders and affiliated companies, and any person/s having greater than $10 \%$ ownership interest in all such persons;

b) a description of the nature of the proposed transaction, including a detailed analysis of the resulting scheme of arrangement and summary of its commercial terms;

c) financial information on the persons involved in the proposed transaction, including their annual revenues from all communications markets, identified by specific markets, the value of assets allocated to communications businesses and copies of any recent annual or quarterly financial reports;

d) a description of the communications markets in which the persons involved in the proposed transaction operate; and

e) a description of the effects of the transaction on the control of network: facilities or related infrastructure, including any interconnection or access arrangements with other Licensees.

Thus, similarly, unlike Sections 120, 121, and 131 of the ISA which jointly state a threshold of $30 \%$ control to invoke a SEC antitrust evaluation of a merger/takeover, Regulation 28 of NCC Regulations states only a threshold of $10 \%$ acquisition of the licensed target company is necessary to require the approval of the NCC.

Further, Regulation 29 of NCC Regs further confers on the NCC the power to request supplementary information toward granting an approval:

29. The Commission may request additional information, regarding an application at any time.

However, Regulation 30 of NCC Regs provides additional clarity, contrary to section 122(5) of the ISA, where the SEC has between 20 - 40 days to take an action on cases submitted to it for approval. Regulation 30 of NCC Regs states the time period for the NCC to approve, deny, or initiate inquiry into the business combination requesting approval:

30. Within thirty (30) days of receipt of a fully completed application, including any additional information requested by the Commission, the Commission may:

a) approve, without conditions, the proposed transaction;

b) approve the proposed transaction, with such conditions as the Commission determines are necessary, to

prevent or compensate for any substantial lessening of competition resulting from the transaction;

c) deny approval of the proposed transaction; and

d) issue a notice initiating an inquiry or other public proceeding, regarding the proposed transaction and, following such proceeding, the Commission may take one of the actions described in sub-paragraphs a), b) or c) above.

Regulation 30 of NCC Regs clearly states the right of the applicant to approach the court for a mandamus by allowing an action by a person suffering a legal wrong because of a final agency action and/or inaction, by taking a writ of mandamus to compel an officer or employee of the government to perform a duty owed to the plaintiff/applicant (5 U.S.C. § 706(2) of the Administrative Procedures Act (“APA")).

In the United States, there are comprehensive provisions under the Administrative Procedures Act (5 U.S.C. § 704) of the Administrative Procedures Act ("APA")), allowing for judicial review of agency action (or lack of agency action, or constructive denial) under 5 U.S.C. §§ 701-706 apply to a "final agency action for which there 
is no other adequate remedy in a court.” Heckler v. Chaney, 470 U.S. 821, 828 (1985).

\section{Regulation and Enforcement of Competition Rules under Investment and Securities Act (ISA)}

On June 25, 2007, the Nigerian legislature enacted, and the President assented to, the Investment and Securities Act, 2004 ("ISA 2007"). The ISA 2007, via Section 314(1), repealed, in entirety, its predecessor, the outdated Investment and Securities Act 1999 ("ISA 1999"). The ISA 2007 and its novel provisions of mergers and acquisitions were fashioned after the South African Companies Act of 1973 and the South African Securities Regulation Code on Take-overs and Mergers ("SRP Code"), as enacted by the Securities Regulation Panel ("SRP”). The SRP Code, in turn, was fashioned after City Code on Take-overs and Mergers (1968), enacted by the London Panel on Take-overs and Mergers ("London Code"). Further, in 2013, pursuant to Section 313 of ISA 2007, the Nigerian Securities and Exchange Commission (SEC) enacted the General Rules and Regulations, pursuant to the Investment and Securities Act 2007 (SEC Regs), to govern securities market (Obayemi \& Adegbola, 2014).

Unlike both the FCCB and/or the SEC Regs, Section 131 of ISA 2007 sets a different 30\% threshold for making determination of violation of antitrust rules. Further, Section 118 vests on the SEC the power of merger control, i.e., either to approve or to disapprove any application for intermediate and/or large mergers in Nigeria, with the Federal High court having the power to sanction such mergers. It is, therefore, important to consider, in detail, the provisions of S. 131 of ISA, which provides that where any person:

1) acquires shares, whether by a series of transactions over a period of time or not, which, taken together with shares held or acquired by persons acting in concert with him, carry $30 \%$ or more of the voting rights of the company, or

2) together with persons acting in concert with him, holds not less than $30 \%$, but not more than $50 \%$, of the voting rights and such person or any person acting in concert with him acquires additional shares which increase his percentage of the voting rights.

Such a person must make a take-over bid for the target company, in accordance with the relevant rules and regulations governing corporate take-overs in Nigeria. Finally, where a merger would substantially lessen competition, sections 121, 126, 127, and 128 of ISA 2007 allow the SEC to either refuse/revoke the merger and/or order a break-up of the business combinations, where such lessens competition (ISA 2007: Sections 121, 126, 127 , and 128).

Under section 118 of the ISA 2007, there are three broad categories of merger threshold that constitute merger control requiring approval of the SEC:

a) small merger (transactions involving N500,000,000.00);

b) intermediate merger (transactions between N500,000,000.00 - N5 billion); and

c) Upper merger (transactions involving N5billion and above) (ISA 2007: Section 118).

Further, under Section 131, where an entity acquires shares which carry $30 \%$ of the voting rights of the target company, or where, acting together with affiliates and subsidiaries, the entity acquires between $30 \%-50 \%$ of the voting rights, an offer must be made to the minority shareholders of the same class of stock acquired.

One major concern is with section 121, which gives the SEC the authority to determine whether it appears that a merger is likely to substantially prevent or lessen competition. First, this clearly clashes with NCC's exclusive power under Section 90 of NCA which states that the NCC shall have exclusive competence to determine, pronounce upon, administer, monitor, and enforce compliance of all persons with competition laws and regulations, whether of a general or specific nature, as it relates to the Nigerian communications market, especially where the company involved is listed by SEC.

Second, we contend that the SEC should not be the agency to determine violation of competition rules (ISA 2007: Section 118). This is because mergers and acquisitions tactics that may have been tailored toward achieving monopoly may be too intricately structured with the ingenuity of crafty professionals. Thus, an agency, such as the SEC, which is already inundated with the regulation of the stock markets and the de-materialization of stock certificates, should not to be saddled with an equally daunting function that, ordinarily, ought to be assigned to a separate and independent technical, competent, and important agency, as presently obtains.

Moreover, since the anti-trust rules did not previously exist under the old 1999 ISA, there is the need to develop a firm home-grown set of laws and practical guidance to serve as foundational basis for future coordinated 
practice in anti-trust jurisprudence.

As stated above, in the United States, Federal Trade Commission's Bureau of Competition regulates the anti-trust sector. Similarly, in the United Kingdom, both the Competition Commission and the Office of Fair Trading handle competition regulation. Even in South Africa, where ISA 2007 was borrowed from, the Competition Commission and Competition Tribunal also handle competition disputes.

\section{Companies Income Tax Act, Cap 21 LFN, 2004 (CITA)}

Section 29(12) of the CITA provides that

"no merger, take-over, transfer, or restructuring of the trade or business carried on by a company shall take place without having obtained the Board's direction under sub-section 9 of this section and clearance with respect to any tax that may be due and payable under the Capital Gains Tax Act”.

An approval of the Federal Inland Revenue Service (FIRS), therefore, is a necessary condition for the completion of the process in a merger or acquisition bid. Both the Acquiring and Target companies must obtain the FIRS’ approval.

This entails that copies of the scheme of merger and scheme of arrangement on the consolidation request for FIRS' study and proper evaluation must be provided, in order to ensure that taxes, which may result from the companies' transactions, are correctly assessed and collected.

Under section 29(9)(i) of CITA, the FIRS may require either company directly affected by any direction, which is under the consideration, to guarantee or give security to its satisfaction for payment in full of all tax due, or to become due, by the company, which is selling or transferring such asset or business (CITA: Section 29(9)(i)).

Further, a merger will trigger the cessation and commencement rules, issues relating to loss reliefs, capital allowance reliefs, stamping, capital gains tax, VAT, etc. Without a measure of tax planning, certain income may be taxed twice.

\section{Recent Business Combinations within the Telecom Sector in Nigeria}

In Nigeria, there are presently two (2) specific telecommunications markets in Nigeria: 1) Mobile Telephone Services and 2) International Internet Connectivity.

Mobile Telephone Services is, in turn, divided into two (2) sub-categories, viz, 1) Code Division Multiple Access (CDMA) and 2) Global System for Mobile Communications (GSM). Presently, there are five (5) major operators in each of CDMA and GSM bands. On the one hand, CDMA has Starcomms, Visaphone, Multi-Links, Intercellular, and Zoom Mobile. On the other hand, GSM has MTN, Globacom (Glo), Bharti Airtel Limited (formerly “Zain”), and Etisalat.

Internet Service Providers in Nigeria include: VSAT Nigeria, Megatech Networks, Netcom, Hyperia, Linkserve Limited, Junisat, Direct On PC, Swift Networks Limited, Tara Systems, MetroNG, Skannet - General Data Engineering Services PLC (GDES), Electronic Connections Limited, More Time Information Technologies Limited, Integrated Telekom \& Networks Limited, Cobranet Limited, Hirest Africa limited, Kkontech, Rainbownet Limited, and MWEB Nigeria.

Yet, the history of CDMA in Nigeria is replete with failed attempts at merger and acquisition. In 2003, there were 23 licensed telecom operators in the country, but by 2011, the number had reduced to 16. The list of operators, still active in fixed mobile telephony in Nigeria, includes Visafone, Multi-Links, Starcomms, Zoom Mobile, Intercellular, VGC/MTN, MTS 1st Wireless, 21st Century Technologies, Disc Communications, Witel, Onet (Odua Telecom) XS broadband, Rainbownet, Monarch Communications, Webcom, and NITEL

In April 2007, Alheri Mobile Services was awarded a 3G concession by the NCC, alongside established operators, such as Airtel Nigeria (then known as Celtel), Globacom, and MTN Nigeria. Startup Alheri Mobile Services is a wholly owned subsidiary of local conglomerate, Dangote Group. In August 2008, the NCC launched a probe into Alheri's lack of $3 G$ rollout plan. Thus, in September 2009, local press reported that the company was looking to sell the licence, as it could not afford to keep it, although, at the time, such reports were denied by Dangote Group. Consequently, in December 2010, the license was transferred to Etisalat Nigeria, which, thereafter, acquired a licence to provide third-generation wireless services, through the purchase of Alheri. According to Etisalat Nigeria's CEO, Steven Evans: 
"We are delighted to acquire the 3G licence, which is an essential element of our plans for further developing the market for mobile broadband in Nigeria. We have placed a strong emphasis on offering data services to all our customers. Now, with 3G, we can further develop our data and mobile broadband portfolio and offer our customers even higher levels of service. There is pent-up demand in Nigeria for broadband and we intend to be leaders in satisfying it... Etisalat plans to invest USD400 million next year [2011], USD50 million of which will be spent on 3G equipment, which will initially be rolled out in Lagos, Port Harcourt, and Abuja, with plans to expand coverage to other areas later in 2011.”

Along the same line, Boye Olusanya, Managing Director of Alheri Mobile, commented:

"It makes sense for us to sell Alheri Mobile to Etisalat Nigeria, as we believe that the market here can only sustain four mobile operators in the medium to long-term. We intend to use the capital raised to develop our other assets in the telecoms market and we look forward to deepening our relationship with Etisalat.”

Earlier on, in June 2010, Bharti Airtel, India's largest mobile services company, completed the acquisition of the African operations of Mobile Telecommunications Company (known as Zain), thus, fulfilling the company's ambitions to expand into markets outside India (Ribeiro, 2010). The agreement covers 15 countries in Africa, except Zain's operation in Sudan and its investments in Morocco. Bharti Airtel had acquired Zain Africa for an enterprise value of US\$10.7 billion, giving Bharti Airtel a total customer base of 180 million, including 131 million subscribers it had in India. Bharti also reached a settlement with Broad Communications, the single largest shareholder in Zain Nigeria, following which its chief, Otudeko, would now head Bharti's operations in Nigeria.

In 2007, Telkom South Africa had entered the Nigerian market, Africa's largest telecom market, by investment and subscription, after buying a 75 percent, $\$ 280$ million stake in Multi-Links Communications. The company provides services, including wireless, unified access services, and international data services in Nigeria. In January 2009, Telkom South Africa bought the remainder of Multi-Links Communications.

However, in July 2011, Helio Towers Nigeria has agreed to buy Telkom South Africa’s embattled MultiLinks Communications, ending a legal battle that halted the sale of the company to Visafone Communications Nigeria in May 2011 (Malakata, 2011). Helio Towers Nigeria had taken Telkom South Africa to court for pulling out of a 10-year rental agreement with Multi-Links Communications, which was cancelled by Telkom South Africa, after three years. Telkom claimed the contract had become invalid. In June 2011, the Federal High Court ruled in favour of Helio Towers Nigeria, i.e., that the contract was still valid, therefore, blocking the sale of the company, until the contract controversy was concluded by the two companies.

However, by July 2011, Helio Towers Nigeria agreed to buy Telkom with full ownership and control of Multi-Links Communications. This is against the background that Telkom South Africa pulled out its investment from Nigeria in 2010, following successive losses, despite several turnaround attempts by the company. Thus, Telkom had sought to sell Multi-Links Communications, in order to partly recover its investment. However, the celebrated sale of the company to Visafone Communication Nigeria was short-lived, as it was reversed, following the Nigerian High Court's order.

Some experts in the Nigerian telecommunications industry have said that the release of a number of subscribers on all the three telecoms operators' networks by the Nigerian Communications Commission (NCC) is a healthy development that will stimulate competition and should be sustained (Okonji. 2014).

NCC, at the weekend, released the result of subscribers' growth across telecoms operators' networks for the second quarter of 2014, which showed a drop in subscribers on the MTN and Airtel's networks, and a rise in the subscribers on the Globacom and Etisalat's networks.

The first quarter result on subscriber number, which NCC released in March this year, showed a steady rise among MTN, Airtel, and Etisalat subscribers, but a slight drop in Globacom subscribers.

That had automatically placed MTN as the largest telecoms operator by subscriber number, with 57 million subscribers, followed by Airtel with 25 million subscribers, and Globacom with 23 million subscribers, while Etisalat became the fourth largest operator with 18 million subscribers.

However, the second quarter, which ended in June this year, showed a sharp rise in Globacom subscribers' base from 23 million to 27 million, in June, placing Globacom as the second largest telecoms operator in the country.

Etisalat, which is the fourth entrant into the Global System for Mobile Communication (GSM) market, also had an increase in subscriber number from 18 million to 19 million, in June 2014, but retained its fourth position 
in the new ranking.

MTN, whose subscriber base dipped from 57 million, in March 2014, to 56 million, in June 2014, however, maintained its leadership position, as the largest GSM operator in the country, while Airtel, whose subscriber number also dipped from 25.5 million, in March 2014, to 25.3 million in June 2014, dropped in the ranking from the second largest operator position to the third largest operator position.

Analysing the subscriber growth trend, experts said they were impressed by the first and second quarter results, because they showed a highly competitive trend in the industry, which they described as healthy and good for the entire industry.

Chairman of the Association of Telecoms Companies of Nigeria (ATCON), Lanre Ajayi, told THISDAY that the result was most welcomed because it showed there is competition in the telecoms industry, which subscribers stand to benefit from, in terms of service rollout and service quality.

"One of the roles of NCC is to deepen competition among operators and this can be justified from the results already released by the NCC. But we need to increase the number of licensed GSM operators to further deepen the competition and to expand telecoms services to rural communities.”

Chairman of the Association of Licensed Telecommunications Operators of Nigeria (ALTON), Gbenga Adebayo, told THISDAY that he was pleased with the results, because they are a true reflection of healthy competition in the industry.

"The fact that an operator does not see the particular position it is occupying as a right, the operator will continue to strive in ensuring that it overtakes its competitors in the ranking order. The one on top of the ranking will do everything possible to maintain such position and this calls for more healthy competition that will eventually translate to better service quality offerings from the operators.”

Mr. Adebayo commended the management of NCC for its regulatory role in the industry, and explained that its objectivity and transparency have kept telecoms operators on their toes.

\section{Conclusions}

The above notwithstanding, stakeholders have seen the potential capture of the Nigerian regulatory institutions by a narrow elite that may not see the regulatory institutions as properly balancing the interests of powerful elite with the wider interests of the people with implied potential policy flip-flops (Akanji, 2014).

The thesis of this paper is to make five (5) suggestions for the reform of competition rules in the Nigerian telecom sector and in the larger Nigerian competition/anti-trust legal regime, as well. Thus, while the future of the telecom industry in Nigeria is very bright, we, respectfully, reiterate our earlier submissions for amendments as stated above.

First, we recommend the harmonization of the laws and regulations that make provisions for regulation of anti-trust and anti-competition practices, both in the telecom sector and in the larger Nigerian economic/business regime, as a whole:

a) Nigerian Communications Act, Cap N97, Laws of the Federation of Nigeria (LFN), of 2004 (NCA);

b) Companies Income Tax Act, Cap C21, Laws of the Federation of Nigeria (2004) (CITA);

c) Investment and Securities Act, Cap 29, Laws of the Federation of Nigeria 2004 (“ISA 2007”);

b) Electric Power Sector Reform Act 2005 (EPSR);

e) Federal Competition Commission Bill (FCCB), and

f) Nigerian Competition Practices Regulations (2007), No. 101, Federal Official Gazette Vol. 94 (NCC Regs).

The above legislations stipulate different thresholds and standards, with respect to anti-trust rules. Under Sections 36 and 39 of the FCCB, the threshold for making a determination of domination of the market, in order to make a finding of violation of anti-trust laws, is $40 \%$ control of the market. On the other hand, Regulation 27 of NCC Regs, however, sets a $10 \%$ threshold, as the standard to be adopted by the Nigerian Communication Commission (NCC), in deciding whether or not to approve business combinations and activities in the telecom sector that will/will not constitute anti-trust violations. With respect to ISA, under sections 118/131 governing Securities and Exchange Commission (SEC)'s approval to mergers and acquisitions, the threshold is 30\% - 50\%. Thus, where an entity acquires shares, which carry $30 \%$ of the voting rights of the target company or, where acting together with affiliates and subsidiaries, the acquirer acquires between $30 \%-50 \%$ of the voting rights in a 
target company, the acquirer must make a simultaneous offer to the minority shareholders of the same class of stock acquired. Because it is usually during the application for SEC's approval that SEC has the duty and opportunity to examine whether a violation of anti-competition laws has occurred, the $30 \%-50 \%$ threshold comes into play. The law is that whenever required to consider a merger, SEC shall initially determine whether or not the merger is likely to substantially prevent or lessen competition. Yet, both Section 121 of ISA and Regulation 27 of NCC Regs do not contain express threshold for determining whether or not the merger of telecom operators or the acquisition of an NCC license is likely to substantially prevent or lessen competition.

Harmonization of the minimum threshold for determining whether or not a transaction is likely to substantially prevent or lessen competition (whether in the telecom or other sectors) is of primary necessity, based on the need for uniformity and certainty in law.

Second, we recommend that there must be periodic assessment of the level of Competition in Nigerian Telecommunications Industry to include the following:

1) definition of the market structure, including relevant market segments, which may be subject to ex-ante regulation;

2) review and assessment of the level of competition within each of the identified markets; determining the existence of dominance in one or more markets;

3) review of the conduct and performance of the identified markets, in order to identify any anti-competitive practices; and

4) determining the markets, which will be subject to revised and/or additional ex-ante regulations.

Third, we recommend that all legislation with provisions seeking to regulate competition must be subject to supervisory regulation of the Federal High Court, as obtains under Section 122(6) of ISA, which states thus:

"If the merger is approved by the Commission, the parties shall apply to the court for the merger to be sanctioned and, when so sanctioned, the same shall become binding on the companies and the court may, by the order sanctioning the merger, or by the subsequent order, make provision..."

The mandatory provisions for the Court's sanctions will also obviate the tendency of conflicting standards being adopted by different governmental agencies. It will also help achieve uniformity, consistency, and certainty in competition/anti-trust law in Nigeria.

Fourth, we make a strong recommendation to the National Assembly to hasten the passage of the Federal Competition Commission Bill (FCCB), so that the Federal Competition Commission Agency can be set up, since the regulation of competition within the federation falls under the Exclusive List.

Fifth, while Regulation 30 of NCC Regs sets out the appropriate period (30 days), within which an agency should make a determination upon being vested with jurisdiction to decide whether anti-trust violations have occurred, similarly, under section 122(5) of the ISA, the SEC has between 20 - 40 days to take an action on cases submitted to it for approval. With these divergent provisions, again, we propose harmonization of this period. We suggest that the period stipulated under NCC Regs (i.e. 30 days) be adopted, because it fits into a calendar month that is easy to calculate by all stakeholders.

Finally, we propose a periodic review of market structures, including market segments, which may be subject to anti-trust practices. This should be complemented by continuous reviews of the level of competition within identified telecom markets and periodic determination of the existence of dominance in all telecom markets in Nigeria. Constant monitoring of the telecom market will make stakeholders vigilant.

\section{References}

5 U.S.C. § 706(2) of the Administrative Procedures Act (“APA”).

5 U.S.C. $\$ 704$ of the Administrative Procedures Act (“APA”).

Aihevba, F. (2006). A Critique of The Nigerian Competition Bill 2005.

http://www.aelex.com/media/archive/A\%20CRITIQUE\%200F\%20THE\%20NIGERIAN\%20\%20COMPETITION\%20BI LL\%202005\%20revised.pdf.

Akanmu, O. (2014). Nigeria’s Sobering Competitiveness Rankings, in the Guardian Newspaper, Friday, 26 September 2014. http://www.ngrguardiannews.com/opinion/columnist/180601-akanmu-nigeria-s-sobering-competitiveness-rankings.

American Bar Association (2008). Issues in Competition Law and Policy, Volume 1. 
Awosika, E., \& Obayemi, O. K. (2014) Technology, Media and Telecommunications Review in Nigeria, Chapter 19, The Technology, Media and Telecommunications Review (5th ed.). London: Law Business Research.

CITA 2004, Companies Income Tax Act, Cap C21, Laws of the Federation of Nigeria (2004) (CITA).

DePemphilis, D. M. (2013). Mergers, Acquisitions, and Other Restructuring Activities (5th ed.), Academic Press Advanced Series.

Dimgba, N. (2009). Regulation of Competition through Merger Control: Case under the Investment and Securities Act 2007, a Paper presented on Tuesday, April 21, 2009 at the Just-Concluded Conference by Section on Business Law (SBL) of the NBA, at Abuja.

Fagbure, A. (2014). More of Mergers and Acquisitions. This Day Lawyer, September 23, 2014, at Page 12.

Federal Competition Commission Bill (2005). The Bill Is Cited as a Bill for an Act to Encourage Competition in the Economy by Prohibiting Restrictive Trade Practices, Controlling Monopolies, Concentrations of Economic Power and Prices, and for Connected Purposes. http://nassnig.org/nass/legislation2.php?search=competition

First City Monument Bank Plc (FCMB) Has Been Named the "Best Telecom Supporting Bank in Nigeria”. http://www.fcmb.com/fcmb/about-us/information-on-finbank-merger/43-media-centre/press-releases/134-helios-towers-ni geria-htn-closes-on-a-250-million-ifc-led-financing.

Global Competitiveness Index 2013-2014: Table 3: The Global Competitiveness Index 2013-2014 Rankings and 2012-2013. http://www3.weforum.org/docs/GCR2013-14/GCR_Rankings_2013-14.pdf

Global Competitiveness Report 2013-2014. http://reports.weforum.org/the-global-competitiveness-report-2013-2014/\#.

Heckler v. Chaney, 470 U.S. 821, 828 (1985).

ISA (1999). Investment and Securities Act, Cap L24, Laws of the Federation of Nigeria, 1999 (“ISA 1999”).

ISA (2007). Investment and Securities Act, Cap 29, Laws of the Federation of Nigeria (2004) (“ISA 2007”).

Malakata, M. (2011). Helio Towers Nigeria Buys Multi-Links Communication. Computerworld Zambia.

NCA 2004 Decree No. 75 of 1992. This Is Now Replaced by the Nigerian Communications Act, Cap N97, Laws of the Federation of Nigeria (LFN), of 2004 (NCA 2004).

NERC 2005, Electric Power Sector Reform Act 2005.

Nigerian Competition Practices Regulations (2007). No. 101, Federal Official Gazette Vol. 94, (Government Notice No. 70) (“NCC Regs”).

Obayemi, O. K. (2014). Legal Validity of Tax Opinions/Advance Tax Rulings in Nigeria: Revisiting Saipem Contracting Nigeria Ltd \& Ors vs. Federal Inland Revenue Service \& Ors, Suit No.: FHC/L/CS/1081/09. This Day Lawyer, 30 September 2014, 12.

Obayemi, O. K., \& Adegola, O. O. (2014). Mergers, Acquisitions and Anti-Trust Rules, under the Investment and Securities Act, 2007. This Day Newspaper, 29 July 2014, 7.

Okonji, E. (2014). Experts Call for Sustained Competition in Telecoms Sector. This Day Newspaper, 25 September 2014. http://www.thisdaylive.com/articles/experts-call-for-sustained-competition-in-telecoms-sector/189864/

PanAfrican Capital Plc (2011). Industry Report, Nigerian Cement Industry...A Review of Opportunities and Recurrent Price Hike. http://www.panafricancapitalplc.com/downloadi.php?id=3

Ribeiro, J. (2010). India’s Bharti Airtel Completes Acquisition of Zain Africa. IDG News Service.

Shaffer, S. (1992). Competition in the US Banking Industry. Economics Letters, 29, 321-323.

Shaffer, S. (2004). Patterns of Competition in Banking. Journal of Economics and Business, 56, 287-313. http://dx.doi.org/10.1016/j.jeconbus.2003.10.003

Ugwunta, D. O., Ani, W. U., Ugwuanyi, G. O., \& Ugwu, J. N. (2012). The Structure of the Nigerian Banking Sector and Its Impact on Bank Performance. Journal of Economics and Sustainable Development, 3, 30.

We Are Social, Global Digital Statistics 2014. http://www.slideshare.net/wearesocialsg/social-digital-mobile-around-the-world-january-2014

Web Trends Nigeria (2009). Nigeria Internet Users Tops 11 Million, Penetration Now 7.8\%. http://webtrendsng.com/blog/nigeria-internet-users-tops-11-million-penetration-now-7-8/

WTO Background Document (1997). The WTO Negotiations on Basic Telecommunications. World Trade Organization, 17 February 1997. 
Scientific Research Publishing (SCIRP) is one of the largest Open Access journal publishers. It is currently publishing more than 200 open access, online, peer-reviewed journals covering a wide range of academic disciplines. SCIRP serves the worldwide academic communities and contributes to the progress and application of science with its publication.

Other selected journals from SCIRP are listed as below. Submit your manuscript to us via either submit@scirp.org or Online Submission Portal.
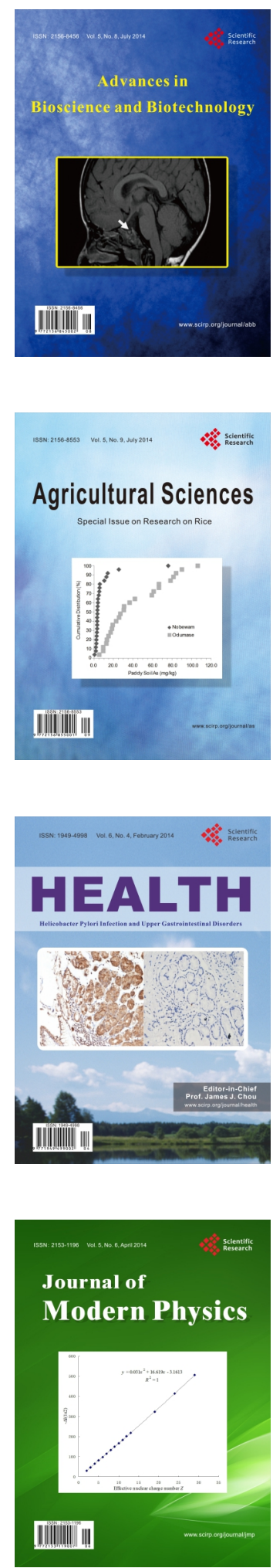
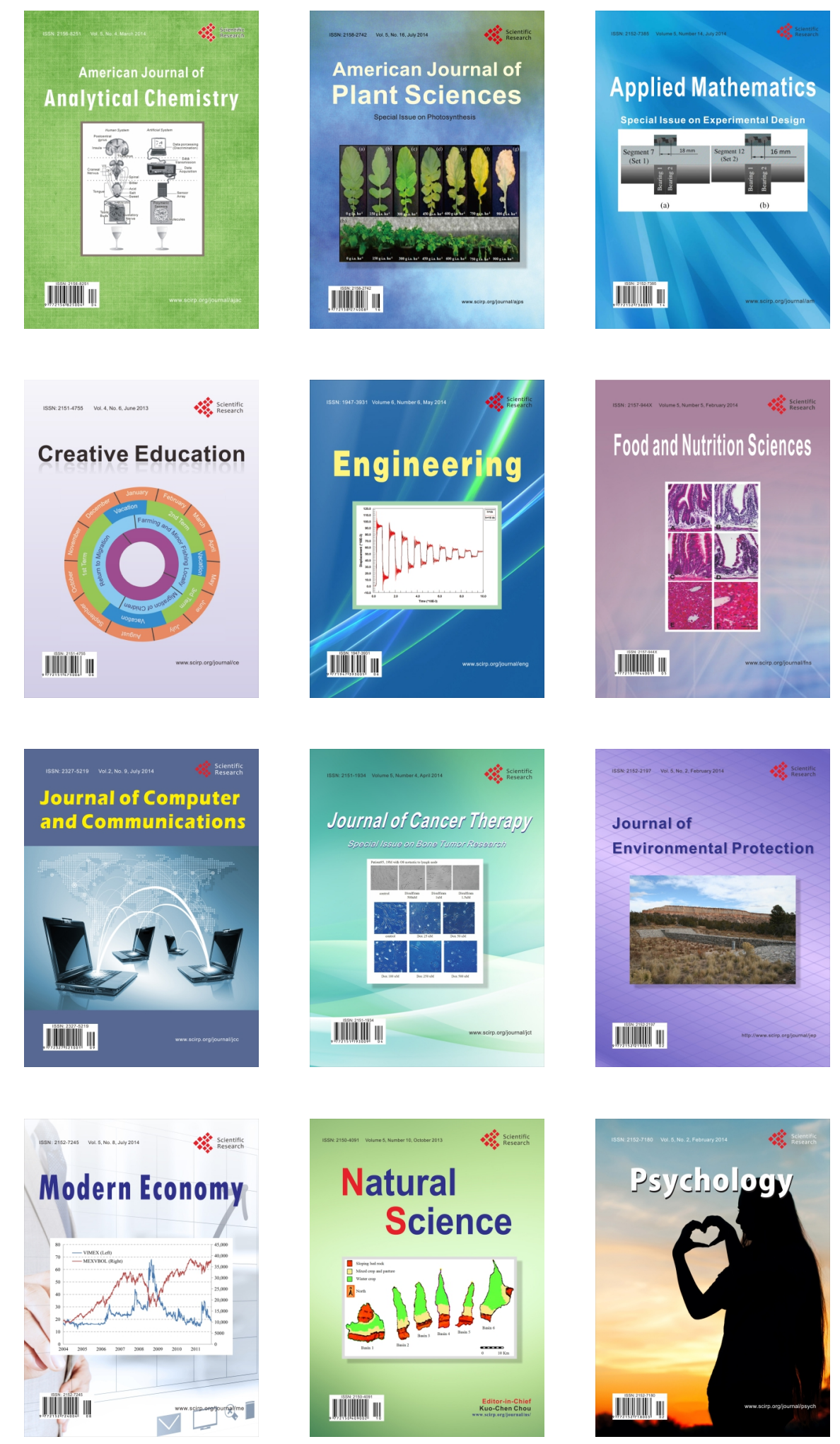